\title{
The AE404 antibody recognizes a Pseudomonas aeruginosa $P A O 1$ surface antigen by flow cytometry
}

Imen Ayadi

Cell Physiology and Metabolism Dpt, University of Geneva, 1 rue Michel Servet, CH-1211, Geneva, Switzerland

\begin{abstract}
The recombinant antibody AE404 detects by flow cytometry P. aeruginosa PAO1 strain; AE409 and AF389 antibodies do not.
\end{abstract}

\section{Introduction}

Pseudomonas aeruginosa is a Gram-negative bacterium classified as one of the ESKAPE pathogens which are drug-resistant and responsible for nosocomial infections (Rice, 2008). Here, we demonstrate the ability of the recombinant antibody AE404 (but not AE409 and AF389) to bind live $P$. aeruginosa PAO1 strain, as detected by flow cytometry.

\section{Materials \& Methods}

Antibodies: ABCD_AE404, ABCD_AE405, ABCD_AE406, ABCD_AE407, ABCD_AE409, ABCD_AF389 and ABCD_AQ601 antibodies (ABCD nomenclature, https://web.expasy.org/abcd/) were produced by the Geneva Antibody Facility (http://www.unige.ch/medecine/antibodies/) as miniantibodies with the antigen-binding portion fused to a mouse IgG2A Fc. The synthesized scFv sequences (Twist Bioscience) correspond to the sequences of the variable regions joined by a peptide linker (GGGGS) ${ }_{3}$ (see Table 1 for clone names and references). HEK293 suspension cells (growing in FreeStyle ${ }^{\text {TM }} 293$ Expression Medium, Gibco 12338) were transiently transfected with the vector coding for the scFv-Fc of each antibody. Supernatants (see Table 1 for production yields) were collected after 4 days.

Table 1: Clone number, epitope, reference and production yields for the antibodies used in this study.

\begin{tabular}{|c|c|c|c|}
\hline ABCD & Target & References & $\begin{array}{c}\text { Yield } \\
(\mu \mathrm{g} / \mathrm{mL})\end{array}$ \\
\hline AE404 & $\begin{array}{c}\text { LPS, } \\
\text { O5 O-antigen }\end{array}$ & \multirow{4}{*}{$\begin{array}{l}\text { Emara et al., } \\
1995\end{array}$} & 40 \\
\hline AE405 & $\begin{array}{c}\text { LPS, } \\
\text { O6 O-antigen }\end{array}$ & & $<5$ \\
\hline AE406 & $\begin{array}{c}\text { LPS, } \\
\text { inner core moiety }\end{array}$ & & $<5$ \\
\hline AE407 & $\begin{array}{c}\text { LPS, } \\
\text { outer core moiety }\end{array}$ & & $<5$ \\
\hline AE409 & $\begin{array}{c}\text { LPS, } \\
\text { O6 O-polysaccharide }\end{array}$ & $\begin{array}{l}\text { Pollack et al., } \\
1995\end{array}$ & 20 \\
\hline AF389 & $\begin{array}{c}\text { LPS, } \\
\text { O6ad O-polysaccharide }\end{array}$ & $\begin{array}{l}\text { Hemachandra et } \\
\text { al., } 2001\end{array}$ & 80 \\
\hline AQ601 & SARS-CoV S protein & $\begin{array}{l}\text { Coughlin et al., } \\
2007\end{array}$ & 50 \\
\hline
\end{tabular}

Antigen: The PT5 strain is a wild-type $P$. aeruginosa PAO1 isolate (Köhler et al., 2000). P. aeruginosa PT5 was cultivated overnight at $37{ }^{\circ} \mathrm{C}$ in $3 \mathrm{~mL}$ of $\mathrm{SM}$ medium (Froquet et al., 2009).

Protocol: $2 \mathrm{~mL}$ of bacterial culture were centrifuged for 3 $\mathrm{min}$ at $8000 \mathrm{rpm}$. Bacteria were resuspended in $2 \mathrm{~mL}$ of SBS buffer $\left(2 \mathrm{mM} \mathrm{Na} \mathrm{HPO}_{4} \cdot 2 \mathrm{H}_{2} \mathrm{O}, 14.7 \mathrm{mM} \mathrm{KH}{ }_{2} \mathrm{PO}_{4}\right.$, $100 \mathrm{mM}$ sorbitol, $\mathrm{pH}$ 6.0) and pelleted again. All subsequent steps were performed in SBS buffer. Bacteria were resuspended in $2 \mathrm{~mL}$ of buffer and diluted 1/100. A shaken suspension of diluted bacteria $(200 \mu \mathrm{L})$ was incubated for 10 min with the indicated primary antibody (2 $\mu \mathrm{g} / \mathrm{L})$ at room temperature. Bacteria were then centrifuged, washed with $1 \mathrm{~mL}$ of buffer, resuspended in $400 \mu \mathrm{L}$, and incubated with Alexa 488-coupled goat antimouse IgG (Life Technologies A11029, diluted 1/200) for $20 \mathrm{~min}$. Bacteria were washed once with $1 \mathrm{~mL}$ of buffer and resuspended in $400 \mu \mathrm{L}$ before analysis by flow cytometry (BD LSRFortessa Cell Analyzer, 647800E6).

\section{Results}

Bacteria coated with AE404 exhibited a clear fluorescent signal compared with negative controls where no primary antibody was used (Fig. 1, No primary antibody) or where both primary and secondary antibodies were omitted (Fig. 1, No antibody).

Antibodies AF389 and AE409, as well as the negative control AQ601 (an antibody that recognizes the SARSCoV spike protein; Uniprot P0DTC2), did not measurably bind PAO1 bacteria (Fig. 1). AE404 was reported to bind LPS of the O5 group (Emara et al., 1995), while AE409 and AF389 bind LPS of the O6 group (Pollack et al., 1995; Hemachandra et al., 2001). Since PAO1 has been serotyped as belonging to the $\mathrm{O} 5$ group (Burrows et al., 1996), it is logical that only AE404 would bind to the bacteria (Table 1).

Antibodies AE405, AE406 and AE407 had low production yields and were not characterized further. 


\section{References}

Burrows LL, Charter DF, Lam JS. Molecular characterization of the Pseudomonas aeruginosa serotype O5 (PAO1) B-band lipopolysaccharide gene cluster. Mol Microbiol. 1996; 22(3):481-95. PMID: 8939432.

Coughlin M, Lou G, Martinez O, et al. Generation and characterization of human monoclonal neutralizing antibodies with distinct binding and sequence features against SARS coronavirus using XenoMouse. Virology. 2007; 361(1):93-102. PMID: 17161858.

Emara MG, Tout NL, Kaushik A, Lam JS. Diverse VH and $\mathrm{V}$ kappa genes encode antibodies to Pseudomonas aeruginosa LPS. J Immunol. 1995; 155(8):3912-21. PMID: 7561098.

Froquet R, Lelong E, Marchetti A, Cosson P. Dictyostelium discoideum: a model host to measure bacterial virulence. Nat Protoc. 2009; 4(1):25-30. PMID: 19131953.

Hemachandra S, Kamboj K, Copfer J, Pier G, Green LL, Schreiber JR. Human monoclonal antibodies against Pseudomonas aeruginosa lipopolysaccharide derived from transgenic mice containing megabase human immunoglobulin loci are opsonic and protective against fatal pseudomonas sepsis. Infect Immun. 2001; 69(4):2223-9. PMID: 11254577.

Köhler T, Curty LK, Barja F, van Delden C, Pechère JC. Swarming of Pseudomonas aeruginosa is dependent on cell-to-cell signaling and requires flagella and pili. J Bacteriol. 2000; 182(21):5990-6. PMID: 11029417.

Pollack M, Koles NL, Preston MJ, Brown BJ, Pier GB. Functional properties of isotype-switched immunoglobulin M (IgM) and IgG monoclonal antibodies to Pseudomonas aeruginosa lipopolysaccharide. Infect Immun. 1995; 63(11):4481-8. PMID: 7591089.

Rice LB. Federal funding for the study of antimicrobial resistance in nosocomial pathogens: no ESKAPE. J Infect Dis. 2008; 197(8):1079-81. PMID: 18419525.

\section{Conflict of interest}

The authors declare no conflict of interest.

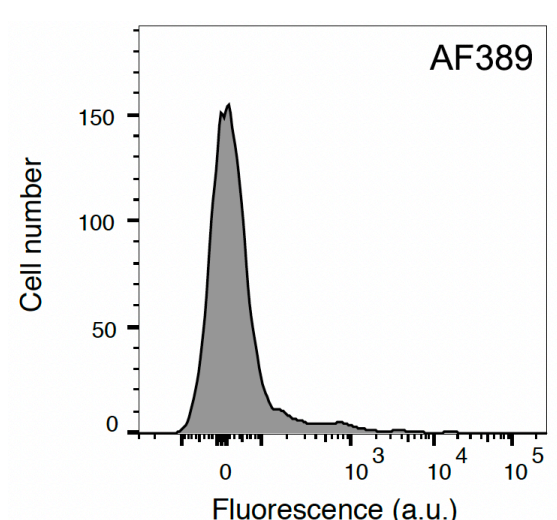

Fluorescence (a.u.)

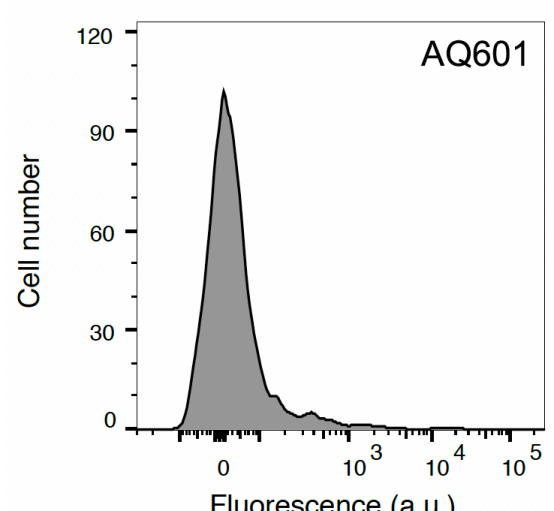

Fluorescence (a.u.)

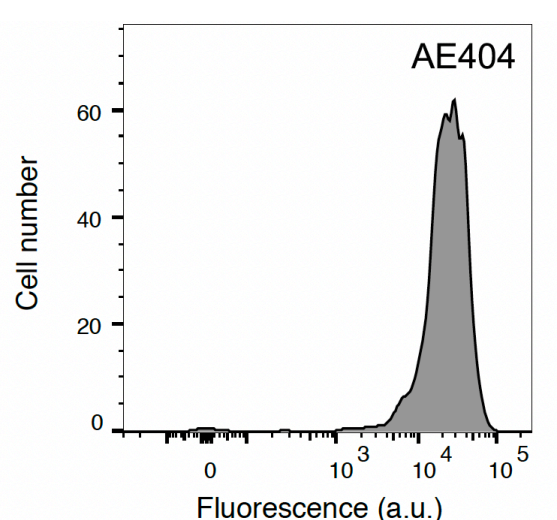

Fluorescence (a.u.)

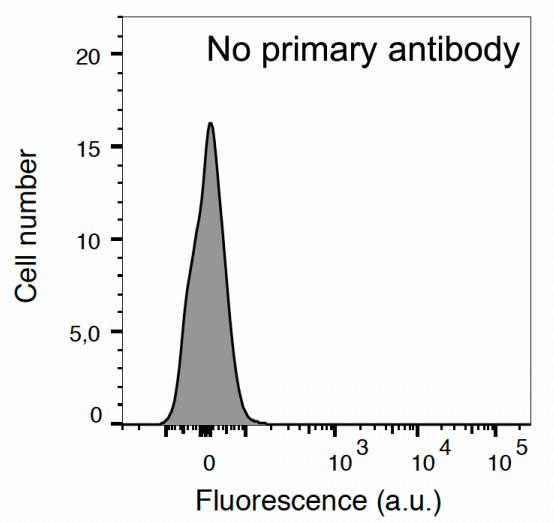

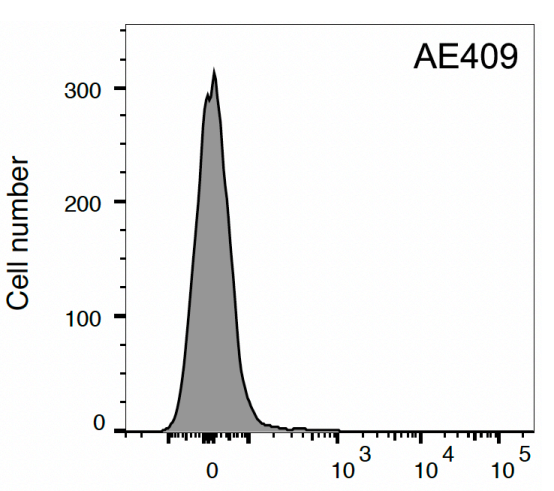

Fluorescence (a.u.)

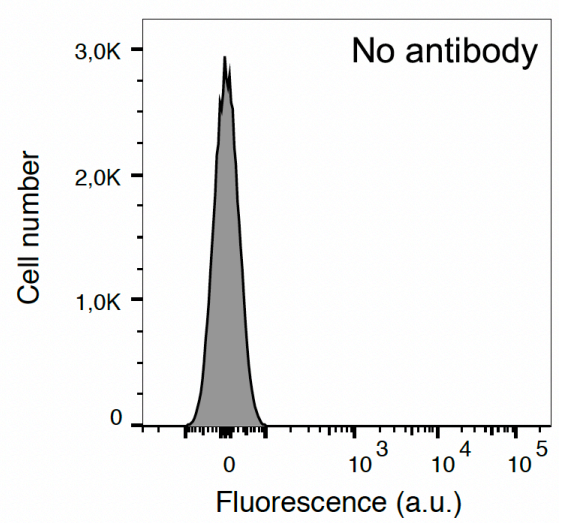

Fig. 1. Live PAO1 P. aeruginosa are coated with AE404, as detected by flow cytometry. Graphs depict the Alexa Fluor 488 signal (Fluorescence axis) vs. the number of events (Cell number axis). AE404 bound specifically to PAO1 bacteria; AF389, AE409 and the negative control AQ601 did not. No labelling was seen when the primary antibody (No primary antibody) or the primary and secondary antibodies (No antibody) were omitted. 